\title{
Finland, A Package Deal: Disciplinary Climate in Science Classes, Science Dispositions and Science Literacy
}

\author{
Larry J. Grabau ${ }^{1, * \mathbb{C}}$, Jari Lavonen ${ }^{2} \mathbb{D}$ and Kalle Juuti ${ }^{2}$ \\ 1 Department of Plant and Soil Sciences, University of Kentucky, Lexington, KY 40546, USA \\ 2 Faculty of Educational Sciences, University of Helsinki, 00014 Helsinki, Finland; jari.lavonen@helsinki.fi (J.L.); \\ kalle.juuti@helsinki.fi (K.J.) \\ * Correspondence: larry.grabau@uky.edu
}

Citation: Grabau, L.J.; Lavonen, J.; Juuti, K. Finland, A Package Deal: Disciplinary Climate in Science

Classes, Science Dispositions and Science Literacy. Sustainability 2021, 13, 13857. https://doi.org/10.3390/ su132413857

Academic Editor:

Michail Kalogiannakis

Received: 12 November 2021 Accepted: 10 December 2021 Published: 15 December 2021

Publisher's Note: MDPI stays neutral with regard to jurisdictional claims in published maps and institutional affiliations.

Copyright: (c) 2021 by the authors. Licensee MDPI, Basel, Switzerland. This article is an open access article distributed under the terms and conditions of the Creative Commons Attribution (CC BY) license (https:// creativecommons.org/licenses/by/ $4.0 /)$.

\begin{abstract}
Finland's educational prowess, though tempered by recent international assessments, has remained intact. This report focused on lessons that could be learned regarding secondary-level science education from the Program for International Student Assessment (PISA) 2015, sciencefocused assessment. That PISA iteration included not only science literacy but also students' science dispositions (epistemology, enjoyment, interest, and self-efficacy) and the schools' science climate measures (disciplinary climate and teaching support). Due to the hierarchical nature of the PISA data, multilevel models were employed in this Finnish study, involving 5582 students from 167 schools. Science dispositions (as outcome measures) were differently associated with teaching support and disciplinary climate (epistemology with neither; enjoyment and interest, with both). Science literacy (as an outcome measure) was associated with all four science dispositions, whether modeled with each science disposition separately or all four simultaneously. Science literacy was also associated with the disciplinary climate in science classes for all tested models. We concluded that, in the Finnish context, science dispositions and the disciplinary climate were predictive of science literacy. Furthermore, we presented evidence from the literature indicating that these conclusions may well extend to other international contexts.
\end{abstract}

Keywords: school science climate; disciplinary climate; science dispositions; epistemology; enjoyment; interest; self-efficacy; science literacy

\section{Introduction}

Finland's educational journey, from a decidedly ordinary past to its current highfunctioning status, has proved to be of enduring interest internationally [1]. While reading literacy has been a particularly strong area for Finland, triennial evaluations by the Program for International Student Assessment (PISA) have revealed high student performance in mathematics and science as well [2-4]. Even in the face of modest declines in science literacy outcomes $[3,4]$, this nation has continued to attract interest from international educators. Sahlberg [1] identified multiple underlying causes for Finland's educational strength, including the national prominence of teaching as a profession (drawing many of their very best students), ongoing professional development programs (finely tuned to teachers' interests), solid financial support for schools (minimizing school-to-school variability in literacy outcomes), and also the firm rejection of "answers" to educational concerns that involve frequent high-stakes testing, extensive homework and tutoring, and national/regional control of content and practice. We note that the science curriculum in Finland emphasizes science literacy as an essential outcome for all students [5], underscoring the value ascribed to science literacy by the Finnish educational community. Furthermore, the literature review below was crafted to provide readers with a brief introduction to the context of this research by reviewing published papers that were both current and relevant. 
In a global context of increasing concern about the misunderstanding (and even outright rejection) of science as a contributor to personal life choices and to public decisionmaking [6,7], enhanced science literacy as an outcome for secondary education is absolutely critical [8]. Some authors [9] have argued that "open-mindedness", particularly as evinced by the adaptive intellectual traits of humility, courage and diligence-as opposed to the maladaptive intellectual traits of arrogance, cowardice and laziness [10]—needs to be developed among the world's populace. In contrast with the highly stratified secondary schools of some European nations (e.g., Benelux nations, Germany), Finland employs a "paraskoulu" (that is, "best school") system of primary and early secondary education. The goal of this "best school" system is to ensure that all schools are of consistently high quality; the mechanisms utilized in the pursuit of that goal include masters-level teacher training programs that produce teaching professionals [11,12], along with local curricular planning, teacher-conducted assessments of effectiveness, and numerous other innovations [13,14]. This approach has successfully "raised all boats"; that is, helped students across schools to attain higher science literacy $[15,16]$. In contrast, several European nations stratify students by track and grade; for example, Dutch-speaking Belgium's system (invoking significant grade retention and aggressive tracking) has trifurcated science literacy, with substantial differences in science literacy among the three main tracks in early secondary schools [17].

Science achievement has been assessed using a wide variety of metrics (grades in science classes [18,19], performance on standard science content evaluations [20], or largescale international assessments [21,22]). Science literacy has been the focus of PISA's science assessment since its first science-focused interaction (in 2006); a key part of PISA's science literacy construct [23] is that students are asked to use what they know about science to develop solutions to complex science problems (versus simply supplying science information or solving routine science problems with a variety of included data). Some nations (for example, Greece) may be disadvantaged by the PISA science assessment, since their instructional models for science focus more on information retrieval and solving routine problems [24]. The PISA science-focused cycles $(2006,2015)$ have included both science dispositions (e.g., enjoyment, interest, self-efficacy) as well as selected science-teaching methods (hands-on activities and student investigations in 2006 [25], and disciplinary climate and teaching support-both in science classes in 2015 [26]).

Science dispositions have been shown to be associated with science literacy in a variety of international contexts $[17,25,27,28]$. Science enjoyment generally relates to a positive attitude toward science, particularly science learning processes [27,29]. Science interest indicates that a student has inclinations toward a particular science discipline (or multiple science disciplines) $[29,30]$. Note that this concept represents a broader construct of interest in science than does the "situational interest/situational engagement" widely investigated by Finnish researchers and their colleagues [31-34]. Students with high science self-efficacy believe that they "can do" particular science-related tasks successfully [27]. Science epistemology generally refers to students' beliefs about the nature of science [20,35-37]; in the PISA 2015 context, an adaptative suite of student beliefs about science epistemology involves both an emphasis on experimentation and on the changeability of science inferences [38]. Hereinafter, we simply refer to the aforementioned science dispositions as enjoyment, interest, self-efficacy and epistemology.

Importantly, research in Finland [32,39] and elsewhere [22,27,29,30,40] has considered how certain teaching methods in science classes (which we will generally term the "school science climate") may promote such science dispositions. Indeed, if science dispositions may be associated with enhanced science literacy, the school science climate (primarily experienced by students in their science classrooms) may very well be an important agent by which science teachers (and, thus, schools) are able to foster adaptive science dispositions. The school science climate has been primarily evaluated based on teachers' methods in science classrooms [22,27,29,30,40]; however, an innovation of the 2015 iteration of PISA was to ask individual students to evaluate their experiences in science classrooms [41]. Two key measures-disciplinary climate (in science classrooms) and teaching support (also in 
science classrooms) - were collected at the student level and designed to be aggregated to the school level. Prompts regarding the disciplinary climate focused on factors that allowed the whole class to "get down to business" in terms of learning about science (e.g., moving past distractions at the outset of class sessions quickly, on to the day's science concepts). Items included in order to construct teaching support in science classes similarly asked about students' experiences of teachers helping them to understand the concepts (versus leaving them to struggle). From a study of 21 nations/regions from PISA 2015, these two key school science climate measures were often associated with a pair of science dispositions-epistemology and enjoyment—as well as with science literacy per se [26]. A comparative study of classrooms, teachers and schools found that school-level features were more important predictors of science achievement than the other two measures [42].

Given the equity-promoting nature of Finnish schools [15,16], along with Finland's strong focus on teacher training [11,12] and teacher empowerment [13,14], we believed that an investigation of the associations among science dispositions, the school science climate, and science literacy could well provide lessons of interest to international science educators. In particular, identifying the extent to which science teaching interventions may enhance science dispositions could allow educators to more finely attune such outcomes. In addition, determining the strength of the associations between specific science dispositions and science literacy as an outcome could help educators to select those science dispositions most likely to have the potential to enhance science literacy. To achieve those ends, our twin research questions for this project were: (i) might the school science climate, over and above student background and school context, be associated with students' science dispositions; and (ii) might the school science climate and/or students' science dispositions (once again, over and above student background and school context) be associated with science literacy?

\section{Materials and Methods}

Data for this research were drawn from the most recent PISA iteration (2015) that was science-focused [3]. The corresponding dataset [43] provided a range of science dispositions (at the student level) along with an intriguing pair of school science-climate measures (aggregated, for our purposes, to the school level). We took advantage of this combination of observations to explore their relationships with science literacy, the specific measure of science achievement assessed under the PISA construct. Owing to the hierarchical nature of the data, with some measures relating to students within schools and others being expressed at the school level, we chose to implement multilevel modeling methods as our analytical tool. The ensuing sections describe data collection approaches, characterize outcome measures, and expand upon our analytical approaches.

\subsection{Data Collection}

National-level research specialists identified schools for participation in each round of the triennial PISA cycle; these schools were chosen to represent, as well as possible, the full range of school contexts (e.g., student enrollment, community size) expressed in that nation. For Finland in 2015, this sample included 167 schools. Within each school, approximately 35 students from the 15-year-old cohort were randomly chosen for this assessment (if a school had fewer than 35 students, all students were included). For Finland in 2015, this sample included 5882 students. Sampling weights at both the student and school levels were provided in the datasets [43] and were invoked as part of the analysis below. Missing values at both student- and school levels were managed differently. Missing values for students were treated at the analytical step of multilevel modeling; meanwhile, missing values for schools were treated by using the multiple imputation function within SPSS [44].

\subsection{Outcome Measures}

In the case of our first research question, four science dispositions (epistemology, enjoyment, interest, and self-efficacy) were successively treated as outcome measures. For 
our second research question, science literacy was the required outcome of a series of multilevel models. While not treated as outcome measures, two school science climate variables (the disciplinary climate in science classes and teaching support in science classes) were considered in both sets of multilevel models.

Tables A1 and A2 provide detailed information on the constructs that gave rise to the above suite of science-related variables (students' science dispositions and the school science climate). Here, we provide a brief characterization of each of these science measures, within this PISA context [38]. Among science dispositions, epistemology was tied to students' beliefs in experimentation and the possibility of change in scientific inferences. The variable of enjoyment is related to the positive emotions experienced by a student while learning science. The variable of interest took a composite look at students' interest in a series of scientific disciplines. Self-efficacy was derived from the level of students' agreement with statements about their ability to complete specific science-related tasks.

Science literacy, in the PISA context, refers to a student's capacity to implement science in actual life settings; specifically, it is "the ability to understand the characteristics of science and the significance of science in our modern world, to apply scientific knowledge, identify issues, describe scientific phenomena, draw conclusions based on evidence, and the willingness to reflect on and engage with scientific ideas and subjects" [23], p. 22. Note that science literacy was defined in the same way for the 2015 iteration of PISA; one key change was the move from five to ten plausible values for the later study. Other, more nuanced, constructions of science literacy exist $[6,7,45]$; however, the ready availability of the PISA-derived data based on the above framework for science literacy made it useful for this project.

The disciplinary climate and teaching support for science were both measured in the context of science classes; in addition, both were assessed at the student level but then aggregated to the school level. In this way, we were able to develop student-driven, schoollevel assessments of both of these school science climate measures. Such student ratings (to assess other teaching approaches) have been validated in a substantive way for 69 PISA 2015 nations/regions [46]. The disciplinary climate essentially addressed the degree to which the science classroom was orderly-getting onto the lesson topic promptly, students being able to hear the teacher, and other variables. Teaching support was related to the sense that individual students' learning mattered to the teacher, that it mattered enough for them to make sure that students were grasping the science ideas being considered.

\subsection{Analytical Approaches}

Our premise was that additional student- and school-level variables, apart from the science-related measures presented above, could also be associated with the outcome measures of science dispositions (research question \#1) and science literacy (research question \#2). Thus, we identified a series of likely candidate variables from among both student background and school context measures, then included those potentially important variables at the appropriate level of our multilevel models [47].

\subsection{Exogenous Variables}

Seven student-background measures were included in these analyses: gender (dummy), age, immigration background (double dummy), home language (double dummy), and an index of economic, social and cultural status (ESCS index). For gender, males were coded as 1, females as 0 ; no alternative gender identities were included as options on the student questionnaire. Student age was reported in years (within a 12-month bracket centered around 15.75 years). Immigration background considered second-generation immigration status as the reference group (coded as 0 for both dummy variables). Native and first-generation immigrant statuses were each coded as 1 for two separate dummy variables. Similarly, a Swedish home language was the reference group (coded as 0) for both dummy home language variables. Finnish home language and all other home languages were each coded as 1 for the two separate dummy variables regarding home 
language. Note that home-language coding (for both dummy variables) was based on a match between students' home language and the language in which they took the PISA assessment. Setting aside those students for whom home languages were not recorded (61 and 5 of whom took Finnish and Swedish assessments, respectively), the vast majority of the assessments were taken in Finnish, by Finnish home-speakers (5213/5473; 95.2\%). Meanwhile, a less substantial majority of Swedish assessments were taken by Swedish home-speakers (254/343; 74.1\%). Of the other home languages group, 246 took the Finnish assessment, while only 6 took the Swedish assessment. In addition, Finnish home-speakers who took their assessment in Swedish ( $n=83 ; 1.6 \%$ of the total Finnish home-speakers) and Swedish home-speakers who took their assessment in Finnish $(n=14 ; 5.2 \%)$ were assigned to the "other home languages" dummy variable, based on a mismatch between their home language and the language of their assessment. Finally, the ESCS index, while showing substantial variability, averaged somewhat higher than the standardized OECD mean for this index (0.259 versus 0.000$)$.

In addition, four school context variables were included: school location, school size, index of the proportion of science teachers who were fully certified, and ESCS indexaggregated (from the student level). School location (as a dummy variable) compared schools located in communities of 100,000 or more residents (coded as 1) with those schools located in smaller communities (coded as 0). School size, reported by PISA as actual enrollment counts, was indexed to a basis of 1000 students (in order to make our primary tables more readable). The remaining pair of school context variables (proportion of teachers certified (ESCS index-aggregated)) were also included to capture a variability in outcome measures that is potentially explained by school context features.

\subsection{Multilevel Modeling}

In order to properly address the data hierarchy inherent in this PISA dataset, we made use of multilevel modeling strategies $[47,48]$. Our chosen software package was HLM8 [49]. For our first research question, four successive models were run (one for each of the four science dispositions under consideration as outcome measures). For our second research question (for which science literacy was the outcome), six successive models were invoked-a "basic" model (that included all student background variables, as well as all school context and school climate variables), four models that each included one of the four science dispositions, as independent variables (in addition to all variables from the basic model), and one "combined" model that included any of the science dispositions that achieved both significance $(p<0.05)$ and at least a small effect size $(d \geq 0.20)$, once again, in addition to all variables from the basic model.

For all models, the full maximum likelihood approach was utilized; in addition, PISAsupplied weighting factors were included at both the student and school levels. Null models were run for all outcome variables (science dispositions as well as science literacy); such null models allowed us to not only identify the proportion of student- and school-level variance accounted for by subsequent models but also allowed us to calculate intraclass correlation coefficients (ICC), which can help determine the propriety of the inclusion of school-level analyses. In pursuit of parsimonious models, we included all student-level variables (level one included student background for both research questions, and science dispositions, as applicable, for research question \#2 only) in the initial model. Student-level variables with the least significant results were iteratively dropped from the level-one model until all remaining variables met the $p<0.05$ criterion. At that point, all school-level variables were loaded into the level two model; once again, the least significant variable was removed from successive model iterations until all level-two variables were also significant at $p<0.05$. In order to evaluate model performance, we calculated the proportion of variance explained at both the student and school levels for each parsimonious model [48]. Finally, in order to assess the effect size of each significant variable, we calculated Cohen's $\mathrm{d}$ (by dividing the variable's modeled coefficient by its standard deviation). We used 
Cohen's [50] relativization of effect sizes ( 0.20 to 0.49 was taken as small; 0.50 to 0.79 , as medium; and $\geq 0.80$ as large).

\section{Results}

Additional materials for this paper include Tables A1 and A2 (providing the underlying prompts used to construct science dispositions and school climate measures, respectively [23]), as well as descriptive statistics (Table A3) and bivariate correlations among science dispositions (Table A4) and school-level variables (whether context or climate; Table A5). Selected information from those Additional materials is briefly noted here. For example, the Finnish sample implemented for this research included $96 \%$ native students, $89.6 \%$ of whom spoke Finnish at home, and a mean ESCS index of 0.259 (indicating that the Finnish mean income exceeded the OECD mean). Science dispositions closely approximated OECD means, as did school climate measures. While bivariate correlations were significant among both science dispositions and school-level variables, only one such correlation (between enjoyment and interest) reached the moderate level among science dispositions (none reached this level among school-level variables).

Table 1 presents the results of multilevel models with each of the four science dispositions treated as outcome variables. Among student background variables, ESCS was the only measure associated with all four science dispositions; this association was positive in each case. Perhaps more intriguingly, home language showed a complex association with epistemology. Students who spoke Swedish at home (and took the PISA assessment in Swedish) showed higher levels of epistemology than either Finnish speakers (who took this assessment in Finnish) or speakers of other languages. Among school climate measures, teaching support in science classes was associated with three of the four science dispositions (epistemology was the exception). One could, thus, argue that school-level teaching support may have promoted enjoyment, interest, and self-efficacy. The disciplinary climate in science classes was significantly (and positively) associated with two of the studied science dispositions: enjoyment and interest. We note that these models accounted for modest proportions of the student-level variance (0.02 to 0.08$)$; in addition, ICC data for these models showed a modest level of school-to-school variability (0.02 to 0.05$)$.

Table 1. Multilevel models for science dispositions (as outcomes) for Finland.

\begin{tabular}{|c|c|c|c|c|c|c|c|c|}
\hline \multirow[b]{2}{*}{ Variable $^{1}$} & \multicolumn{2}{|c|}{ Epistemology } & \multicolumn{2}{|c|}{ Enjoyment } & \multicolumn{2}{|c|}{ Interest } & \multicolumn{2}{|c|}{ Self-Efficacy } \\
\hline & Coeff. & $d^{2}$ & Coeff. & d & Coeff. & d & Coeff. & d \\
\hline \multicolumn{9}{|c|}{ Student background: } \\
\hline Gender $^{3}$ & - & - & - & - & 0.29 & 0.12 & 0.26 & 0.07 \\
\hline Age & - & - & - & - & 0.13 & 0.03 & 0.16 & 0.04 \\
\hline Other home lang. & -0.34 & 0.04 & - & - & - & - & - & - \\
\hline Finn. home lang. & -0.21 & 0.03 & - & - & - & - & - & - \\
\hline ESCS index & 0.23 & 0.16 & 0.25 & 0.16 & 0.23 & 0.13 & 0.31 & 0.17 \\
\hline School context: & & & & & & & & \\
\hline $\begin{array}{l}\text { ESCS ind.-ag. } \\
\text { School climate: }\end{array}$ & - & - & - & - & 0.23 & 0.17 & - & - \\
\hline Disc. clim. sci. cl. & - & - & 0.28 & 0.35 & 0.11 & 0.16 & - & - \\
\hline Tch. sup. sci. cl. & - & - & 0.19 & 0.39 & 0.17 & 0.27 & 0.12 & 0.20 \\
\hline Prop., student var. & \multicolumn{2}{|c|}{0.08} & \multicolumn{2}{|c|}{0.02} & \multicolumn{2}{|c|}{0.06} & \multicolumn{2}{|c|}{0.04} \\
\hline Intraclass corr. & \multicolumn{2}{|c|}{0.03} & \multicolumn{2}{|c|}{0.03} & \multicolumn{2}{|c|}{0.05} & \multicolumn{2}{|c|}{0.02} \\
\hline
\end{tabular}

${ }^{1}$ Significant variables in this column remained in a given model by meeting the $p<0.05$ criterion; all student background and school variables were tested in each model. Those student- and school-level variables that were not included dropped out of all multilevel models shown. ${ }^{2}$ Bolded " $\mathrm{d}$ " values met a minimum 0.20 criterion. ${ }^{3}$ For more complete variable descriptions, please see the Methods section and Appendix A. Dashes (-) in the table indicate that a given variable dropped out of a given model.

Table 2 catalogs the results of our "basic" (no science dispositions included) multilevel model, taking science literacy as an outcome. Student background variables of female gender, increasing age (within the 15-year-old cohort), native status, Finnish home lan- 
guage and ESCS level were each associated with science literacy. Note that the coefficients in this table directly represent the differences among science literacy scores for the contrasting levels of a given variable. For example, female students averaged higher (7.72) PISA scale points than did males. Smaller school size (a school context measure) and a stronger disciplinary climate in science classes (a school science climate variable) were both significantly associated with science literacy in Finnish students. Based on our effect size analysis, Finnish home language, ESCS index, and disciplinary climate were best attested as strongly meaningful. We note that both the proportion of student-level variance accounted for and the ICC measure were moderate for this model.

Table 2. A basic multilevel model for science literacy in Finland (no science dispositions included).

\begin{tabular}{|c|c|c|}
\hline \multirow[b]{2}{*}{ Variable $^{1}$} & \multicolumn{2}{|c|}{ Basic Model } \\
\hline & Coeff. & $d^{2}$ \\
\hline \multicolumn{3}{|l|}{ Student background: } \\
\hline Gender & -7.72 & 0.04 \\
\hline Age & 22.56 & 0.08 \\
\hline Native students & 45.71 & 0.19 \\
\hline Finn. home lang. & 35.38 & 0.45 \\
\hline ESCS & 30.89 & 0.53 \\
\hline \multicolumn{3}{|l|}{ School context: } \\
\hline$\overline{\text { School size (per } 1000)}$ & -25.31 & 0.16 \\
\hline School climate: & & \\
\hline Disc. clim. sci. cl. & 41.80 & 0.32 \\
\hline Prop., student var. & \multicolumn{2}{|c|}{0.10} \\
\hline Intraclass corr. & \multicolumn{2}{|c|}{0.09} \\
\hline
\end{tabular}

${ }^{1}$ Significant variables in this column remained in a given model by meeting the $p<0.05$ criterion; all student background and school variables were tested in each model. No science dispositions were included in this basic model. Variables that were not included failed to meet that criterion for all multilevel models shown. For more complete variable descriptions, please see the Methods section and Appendix A. ${ }^{2}$ Bolded " $\mathrm{d}$ " values met a minimum 0.20 criterion.

Multilevel model results with science literacy as the outcome are shown in Table 3. We focus our comments upon the four science dispositions, along with the only significant school science climate measure, this being the disciplinary climate in science classes. Coefficients and d-values for student background and school context measures are included to underscore our modeling methods; that is, each model included all student background and school-level measures. We focused on the "above and beyond" associations of science dispositions with science literacy, after taking into account a broad portfolio of student background and school context variables. While all four science dispositions were significantly associated with science literacy, the strengths of those associations, as evaluated by effect sizes, differed dramatically. A large effect size was the result for enjoyment; a medium effect size for self-efficacy and epistemology; and a small effect size for interest. Full unit increases (two standard deviations from the mean) in epistemology, enjoyment, interest, or self-efficacy indicated a gain of 19 to 31 scale points in science literacy (all with small effect sizes) when separately included in science literacy models. Meanwhile, the disciplinary climate in science classes was associated with science literacy for all four models, including single science dispositions. A full unit increase in disciplinary climate (again, two standard deviations) was associated with a gain of 30-41 PISA scale points. Thus, the disciplinary climate in science classes could be regarded as promoting science literacy in the presence of all four studied science dispositions. For each model, the proportion of student-level variance that was accounted for was substantially greater than the 0.10 level accounted for by our basic model. 
Table 3. Multilevel models for science literacy in Finland, with science dispositions as independent variables.

\begin{tabular}{|c|c|c|c|c|c|c|c|c|}
\hline \multirow[b]{2}{*}{ Variable $^{1}$} & \multicolumn{2}{|c|}{ Epistemology } & \multicolumn{2}{|c|}{ Enjoyment } & \multicolumn{2}{|c|}{ Interest } & \multicolumn{2}{|c|}{ Self-Efficacy } \\
\hline & Coeff. & $d^{2}$ & Coeff. & d & Coeff. & d & Coeff. & d \\
\hline \multicolumn{9}{|l|}{ Student background: } \\
\hline$\overline{\text { Gender }}$ & -6.49 & 0.05 & -9.70 & 0.06 & -17.20 & 0.08 & -12.64 & 0.09 \\
\hline Age & 19.68 & 0.07 & 21.72 & 0.09 & 18.56 & 0.07 & 20.28 & 0.08 \\
\hline Native students & 36.85 & 0.16 & 71.76 & 0.19 & 56.06 & 0.27 & 46.71 & 0.22 \\
\hline Other home lang. & - & - & - & - & -23.00 & 0.25 & - & - \\
\hline Finn. home lang. & 37.25 & 0.48 & - & - & - & - & 30.41 & 0.38 \\
\hline ESCS & 23.85 & 0.41 & 24.04 & 0.29 & 22.27 & 0.29 & 24.99 & 0.32 \\
\hline $\begin{array}{l}\text { Science disposition } \\
\text { School context: }\end{array}$ & 31.12 & 0.63 & 24.96 & 1.40 & 31.31 & 0.31 & 18.81 & 0.74 \\
\hline $\begin{array}{l}\text { School size (per 1000) } \\
\text { School climate: }\end{array}$ & 24.87 & 0.17 & - & - & - & - & - & - \\
\hline 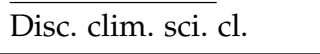 & 39.34 & 0.29 & 30.25 & 0.19 & 31.32 & 0.23 & 40.55 & 0.29 \\
\hline Prop., student var. & \multicolumn{2}{|c|}{0.19} & \multicolumn{2}{|c|}{0.17} & \multicolumn{2}{|c|}{0.20} & \multicolumn{2}{|c|}{0.15} \\
\hline Delta, student var. & \multicolumn{2}{|c|}{0.09} & \multicolumn{2}{|c|}{0.07} & \multicolumn{2}{|c|}{0.10} & \multicolumn{2}{|c|}{0.05} \\
\hline
\end{tabular}

${ }^{1}$ Significant variables in this column remained in a given model by meeting the $p<0.05$ criterion; all student background and school variables were tested in each model. Variables not included in this column dropped out of all multilevel models tested for science literacy as an outcome variable. For more complete variable descriptions, please see the Methods section and Appendix A. ${ }^{2}$ Bolded "d" values met a minimum 0.20 criterion. Dashes (-) in the table indicate that a given variable dropped out of a given model.

For Table 4, we focused on science dispositions and the disciplinary climate in science classes, in the context of our "combined" model. This multilevel model simultaneously considered all four of the studied science dispositions; notably, all four science dispositions remained in our combined model. This indicated that each of the four science dispositions was uniquely associated with science literacy as an outcome in the presence of the other three science dispositions. Effect sizes differed; while epistemology reached a modest effect size, and enjoyment and self-efficacy each achieved a small effect size, interest fell just short of a small effect size. The disciplinary climate in science classes remained in this combined model, testifying to the persistence of its association with science literacy in the presence of the quartet of science dispositions considered.

Table 4. A combined multilevel model for science literacy for Finland.

\begin{tabular}{|c|c|c|}
\hline \multirow[b]{2}{*}{ Variable $^{1}$} & \multicolumn{2}{|c|}{ Combined Model } \\
\hline & Coeff. & $d^{2}$ \\
\hline \multicolumn{3}{|l|}{ Student background: } \\
\hline Gender & -14.98 & 0.12 \\
\hline Age & 16.35 & 0.07 \\
\hline Native students & 42.18 & 0.23 \\
\hline Finn. home lang. & 31.56 & 0.44 \\
\hline ESCS ind. & 16.97 & 0.21 \\
\hline \multicolumn{3}{|l|}{ Science disposition } \\
\hline Epistemology & 22.07 & 0.56 \\
\hline Enjoyment & 6.26 & 0.45 \\
\hline Interest & 19.05 & 0.17 \\
\hline Self-efficacy & 8.62 & 0.44 \\
\hline \multicolumn{3}{|l|}{ School context: } \\
\hline School size (per 1000) & -26.00 & 0.19 \\
\hline \multicolumn{3}{|l|}{ School climate: } \\
\hline Disc. clim. sci. cl. & 33.70 & 0.25 \\
\hline Prop., student var. & \multicolumn{2}{|c|}{0.27} \\
\hline Delta, student var. & \multicolumn{2}{|c|}{0.17} \\
\hline
\end{tabular}

${ }^{1}$ Significant variables in this column remained in a given model by meeting the $p<0.05$ criterion; all student background and school variables were tested in each model. Variables not included failed to meet that criterion for all multilevel models shown. For more complete variable descriptions, please see the Methods section and Appendix A. ${ }^{2}$ Bolded " $\mathrm{d}$ " values met a minimum 0.20 criterion. 


\section{Discussion}

Our research assessed the potential associations of two school science climate variables with science dispositions and science literacy. The disciplinary climate and teaching support (both in science classes) comprise our first focus here. Furthermore, we have termed this pair of concepts "school science climate" variables, since both specifically refer to the context of science teaching, as evaluated by the students themselves. Note that, for purposes of our analysis, we aggregated student responses to the school level for both disciplinary climate and teaching support variables.

Teaching support and the disciplinary climate were both positively associated with some of the science dispositions evaluated in this research; specifically, these two measures of school science climate were positively associated with both enjoyment and interest (Table 1). Given that both enjoyment and interest remained in our "combined" model, as associated with science literacy (Table 4), one could reasonably infer that both of these aspects of the school science climate could be considered promotive of science literacy. In fact, the disciplinary climate was directly associated with science literacy as an outcome measure for all four models, including a single science disposition (Table 3), and was also associated with science literacy in the combined model (Table 4). Thus, we argue that an emphasis on improving the disciplinary climate of Finnish science classes could potentially be a productive approach to improving science literacy in that national context. Variability between Finnish schools in science literacy for PISA 2015 was quite low (less than 10\% between schools, along with Iceland and Norway) in contrast with much more stratified national school systems (nearly 50\% variability in Belgium and Germany, and $65 \%$ in the Netherlands) [16]. However, variability in the measure of interest here (disciplinary climate in science classes, tested at the school level) was indeed associated with science literacy in all the models we tested (Tables 3 and 4 ).

\subsection{School Science Climate, Selected PISA Measures}

Based on PISA 2015 data and invoking multilevel structural equation modeling, potential mechanisms for linkages among students' socioeconomic status (SES), the disciplinary climate in science classes, and science literacy have been investigated in detail [51]. Some support for a "compensation" mechanism was obtained, to wit: "secondary data analysis of the PISA 2015 data from five Nordic countries resulted in consistent and robust evidence supporting the compensation hypothesis, that is, the disciplinary climate's contribution to science achievement above and beyond SES at both the student and school levels" [51], p. 219. Multilevel studies have shown connections among disciplinary climate and science literacy for four Chinese cities (Beijing, Shanghai, Jiangsu, and Guandong) [52]; as well as for Singapore [40]. Notably, the above-mentioned Chinese research was unable to connect teaching support in science classes with science literacy [52]. Recent work has positioned both teaching support and disciplinary climate as associated with a pair of science dispositions (epistemology and enjoyment), as well as with science literacy for many of the 21 diverse nations/regions evaluated in that project [26]. In summary, a diverse suite of studies supports our current conclusions for Finland; particularly, that the disciplinary climate in science classrooms was broadly associated with science literacy.

\subsection{Effective Science-Teaching Models, a Student-Centered View}

Finnish research, as noted above, has recently emphasized students' engagement in science learning on a nearly instantaneous basis [31,32,34,39]. One profound strength of such work is that it assesses students' engagement in science lessons in response to teaching "moments", rather than focusing on teachers' activities alone [33]. Specifically, these recent studies have shown enhanced situational engagement by bringing a playful, interactive, design and test intervention to physics [34]; developing models and crafting explanations [31], inquiry- and problem-based learning approaches as developed via teacher-researcher collaborations [32], and dialog-based teacher talk [39]. We believe that our current paper aligns well with this research—particularly because it focuses on students' perceptions of their 
learning environment (rather than fixating on teachers' strategies and approaches per se). Notably, a broad review of PISA 2015 (69 nations/regions) found that student ratings of four different teaching contexts "captured meaningful differences in teaching quality between schools" [46], p. 275. Estonian research supported teacher-centered science instruction as being connected with positive student outcomes (enjoyment); however, this teachercentered approach remained most prominent in lower secondary classrooms, in spite of teachers' expressed desires to provide a more student-centered learning environment [29]. Of course, in some cases [22], students' perceptions of teaching quality have not been associated with science achievement. Thus, while the responses of a given set of students to specific science teaching and learning environments have been diverse $[21,27,30,53,54]$, we believe that work considering students' own responses to their learning contexts should be highly valued.

\subsection{Science Dispositions}

All four science dispositions were positively associated with science literacy, not only when tested in separate models but also when tested together in a single combined model. That approach-utilizing a combined model-allowed us to identify those science dispositions most strongly associated with science literacy. Epistemology rose to the top in that combined model (with a moderate effect size); meanwhile, enjoyment and self-efficacy both registered a small effect size in that same model. Hence, we focused on epistemology, enjoyment, and self-efficacy. Recent Finnish research has associated students' epistemic beliefs with their science performance [55]; Taiwanese studies have identified student clusters that held simultaneously divergent levels of epistemic beliefs, enjoyment, and science literacy [37]. In a US context, teachers' epistemic orientations were related to their adoption of science teaching practices [56], indicating that efforts to enhance students' epistemic beliefs around science may need to first address their teachers' epistemic beliefs. A causal linkage among epistemic beliefs in science, intellectual risk-taking and science literacy has been detected [20]; enjoyment has been linked with science literacy for a suite of high-performing nations/regions (Canada, China, Finland, and Hong Kong) [27] along with Turkey [40] and the US [25]; and self-efficacy has been associated with science literacy in multiple contexts $[25,27]$. Notably, particular science teaching interventions (models [25,31] and hands-on activities [25,57]) that have evoked situational or sustained interest in science learning have been related to this set of science dispositions. Thus, we suggest that teaching interventions focused on enhancing students' experiences of science may not only be related to enhanced science dispositions but also to elevated science literacy. Furthermore, we suggest that a greater emphasis on the epistemic beliefs of science students may be appropriate.

\subsection{Surprising Home-Language Associations}

While Swedish-speaking students who took the PISA-2015 assessment in Swedish had significantly higher average epistemology than did either Finnish-speakers who took the assessment in Finnish, or other students whose assessment and home languages did not match, the highest average science literacy scores were detected for the Finnish/Finnish group. An understanding of this surprising feature of this study has been elusive; we suggest that the Swedish/Swedish context may require further scrutiny. Particularly, why might an instructional context (Swedish instruction and assessment for Swedish speakers) give rise to higher levels of epistemology, yet show lower science literacy? We note that science teachers are slightly less qualified in Swedish- (93\%) compared to Finnish-speaking (98\%) schools [58], providing at least a rationale for higher science literacy in the Finnishspeaking students. Furthermore, since Swedish-speaking concentrations (and therefore, Swedish language schools) differ between the more rural west coast communities and more urban communities on the south coast, the selection of schools for the PISA sample could influence science-related outcomes. Many global contexts include multiple home languages in PISA samples; it is less common that PISA assessments are offered in multiple 
languages within a given nation/region. Spain is a remarkable example of providing PISA assessments in several local languages; differences in outcomes (for example, science literacy) have been noted in Spain on a provincial scale (roughly corresponding to some of the local languages) [59]. Flemish students whose home language did not match the assessment language scored substantially lower in science achievement than those students not dealing with a language mismatch [60]. Language congruence (taking the PISA assessment in one's home language) has also given rise to surprising results elsewhere; for example, minority French-speaking students in Canada had higher science literacy than either English-speakers or speakers of other languages, while German speakers in Italy had lower test anxiety than did Italian speakers [61]. We suspect that instruction-and assessmentin one's home language may be important not only for students' academic achievement but also for their dispositions toward learning [62]. Perhaps the students' opportunity to demonstrate competence could be improved by enhanced language congruence [63-65]?

\subsection{Conclusions and Limitations}

We draw general conclusions regarding the school science climate, science dispositions, and home language. The disciplinary climate in science classes was associated with science literacy and science dispositions not only in our Finnish research work but also in a variety of other international contexts. More broadly, an emphasis on school science climate could merit more attention. Research drawing upon students' instantaneous and longer-term science engagement appears to have the potential to add substantive value to conversations about well-crafted teaching and learning environments. Furthermore, it seems that the epistemic beliefs of science students may merit a greater focus among research considering science dispositions. There may be a window for expanded research on language coherence and student learning; that is, students may perform better if they are able to experience instruction and assessment in their home languages. In the context of Hong Kong, both lower- and moderate-performing science students benefitted from science instruction in their home (Chinese) language [65].

The primary limitation of this research is the correlational nature of the data upon which it was based. Experimental and/or longitudinal studies can clearly provide more definitive conclusions since their inferences are based on comparisons across treatments or over time. Thus, correlational studies require the support of more definitive research; however, they can obviously provide some intriguing insights as to the directions of that ensuing work. A second limitation relates to the applicability of some of the constructs included in this research. For example, the underlying prompts for epistemology only related to a pair of conceptual underpinnings of students' epistemological beliefs: experimentation (as an important support for students' inferences) and the changeable nature of science's assertions (depending on the emerging results). Obviously, both support for experimentation and comfort with change are important aspects of an adaptative epistemic belief among students; however, other patterns have also been implicated as part of a positive epistemology of science $[35,36]$.

In conclusion, we harmonize with Sahlberg's voice [1] from the third edition of his well-known text. Perhaps his most significant insights centered on contextualization and commitment; that is, could it be that other nations could experience some of Finland's success, not by trying to precisely match their methods but instead through appropriate contextualization of their underlying principles? Furthermore, can one infer from his celebrated review of Finland's educational system that sustained excellence in science education requires a profound commitment to underlying values?

Author Contributions: Conceptualization, L.J.G., J.L. and K.J.; methodology, L.J.G.; software, L.J.G.; validation, J.L. and K.J.; formal analysis, L.J.G.; investigation, L.J.G.; resources, L.J.G.; data curation, L.J.G.; writing —original draft preparation, L.J.G.; writing—review and editing, J.L. and K.J.; visualization, L.J.G. All authors have read and agreed to the published version of the manuscript.

Funding: This research received no external funding. 
Institutional Review Board Statement: Ethical review and approval were waived for this study, since those processes were managed by the research team which collected this publicly available data, rather than the authors of this manuscript.

Informed Consent Statement: Informed consent was obtained from all subjects involved in this study by the national-level managers of the PISA 2015 assessment.

Data Availability Statement: Data utilized in these analyses are available for free download from OECD at the following link: https://www.oecd.org/pisa/data/2015database/ (accessed on 15 October 2021).

Acknowledgments: Both Rianne Janssen (Faculty of Psychology and Educational Sciences, KU Leuven) and Benoit Galand (Faculty of Psychology and Educational Sciences, UC Louvain) supported this project by providing office space at their respective Belgian universities, along with a conducive, collegial research environment during the invited professorships of L.J.G. at their institutions.

Conflicts of Interest: The authors declare no conflict of interest.

\section{Appendix A}

Table A1. PISA Items Descriptive of Science Dispositions.

Epistemology (Epistemological Beliefs) (First term, as utilized in manuscript; second term (in parentheses), as utilized by PISA)

How much do you disagree or agree with the statements below?

(a) A good way to know if something is true is to do an experiment. (b) Ideas in <broad science $>$ sometimes change. (c) Good answers are based on evidence from many different experiments. (d) It is good to try experiments more than once to make sure of your findings. (e) Sometimes $<$ broad science $>$ scientists change their minds about what is true in science. (f) The ideas in $<$ broad science $>$ science books sometimes change. $(1=$ Strongly agree, $2=$ agree, $3=$ disagree, 4 = strongly disagree).

Enjoyment (Enjoyment of Science)

How much do you agree with the statements below?

(a) I generally have fun when I am learning science topics. (b) I like reading about science. (c) I am happy doing science problems. (d) I enjoy acquiring new knowledge in science. (e) I am interested in learning about science. ( 1 = strongly agree, 2 = agree, 3 = disagree, $4=$ strongly disagree).

Interest (Interest in Broad Science Topics)

How much interest do you have in learning about the following science topics?

(a) Topics in physics. (b) Topics in chemistry. (c) The biology of plants. (d) Human biology.

(e) Topics in astronomy. (f) Topics in geology. (g) Ways scientists design experiments. (h) What is required for scientific explanations? ( $1=$ high interest, $2=$ medium interest, $3=$ low interest, $4=$ no interest.

Self-efficacy (Science Self-efficacy)

How easy do you think it would be for you to perform the following tasks on your own?

(a) Recognize the science question that underlies a newspaper report on a health issue.

(b) Explain why earthquakes occur more frequently in some areas than in others. (c) Describe the role of antibiotics in the treatment of disease. (d) Identify the science question associated with the disposal of garbage. (e) Predict how changes to an environment will affect the survival of certain species. (f) Interpret the scientific information provided on the labeling of food items. (g) Discuss how new evidence can lead you to change your understanding about the possibility of life on Mars. (h) Identify the better of two possible explanations about the formation of acid rain. $(1=\mathrm{I}$ could do this easily, 2 = I could do this with a bit of effort, 3 = I would struggle to do this on my own, 4 = I couldn't do this). 
Table A2. PISA Items Descriptive of School Science Climate Variables.

\begin{tabular}{l} 
Disciplinary Climate in Science Classes (aggregated from student level) \\
\hline How often does the following happen? \\
(a) Students don't listen to what the teacher says. (b) There is noise and disorder. (c) The teacher \\
has to wait a long time for students to quiet down. (d) Students cannot work well. (e) Students \\
don't start working until a long time after the lesson begins. (1 = Every Lesson, $2=$ Most Lessons, \\
3 = Some Lessons, 4 = Never or Hardly Ever). \\
Teaching Support in Science Classes (aggregated from student level) \\
How often does the following happen? \\
(a) The teacher shows an interest in every student's learning. (b) The teacher gives extra help to \\
students with their learning. (c) The teacher continues teaching until the students understand. \\
(d) The teacher gives students an opportunity to express opinions. (1 = Every Lesson, $2=$ Most \\
Lessons, 3 = Some Lessons, $4=$ Never or Hardly Ever). \\
Source: [38].
\end{tabular}

Table A3. Descriptive statistics for student- and school-level variables included in the multilevel analysis for Finland.

\begin{tabular}{|c|c|c|c|c|c|}
\hline Variable $^{1}$ & $n$ & Mean & s.d. & $\min$. & $\max$. \\
\hline \multicolumn{6}{|l|}{ Student background: } \\
\hline Male gender & 5882 & 0.513 & 0.500 & 0 & 1 \\
\hline Age & 5882 & 15.720 & 0.284 & 15.250 & 16.250 \\
\hline First-gen. immig. & 5794 & 0.022 & 0.146 & 0 & 1 \\
\hline Native students & 5794 & 0.960 & 0.195 & 0 & 1 \\
\hline Other home lang. & 5816 & 0.060 & 0.238 & 0 & 1 \\
\hline Finn. home lang. & 5816 & 0.896 & 0.305 & 0 & 1 \\
\hline ESCS index & 5812 & 0.259 & 0.748 & -4.112 & 3.567 \\
\hline \multicolumn{6}{|l|}{ Science disposition: } \\
\hline Epistemology & 5462 & -0.071 & 0.941 & -2.790 & 2.155 \\
\hline Enjoyment & 5599 & -0.071 & 1.006 & -2.115 & 2.164 \\
\hline Interest & 5510 & -0.093 & 0.972 & -2.498 & 2.451 \\
\hline Self-efficacy & 5470 & -0.041 & 1.183 & -3.757 & 3.278 \\
\hline \multicolumn{6}{|l|}{ School context: } \\
\hline$\overline{\text { School location }}$ & 167 & 0.275 & 0.448 & 0 & 1 \\
\hline School size & 167 & 411.620 & 217.394 & 15.000 & 1044.000 \\
\hline Sci. teach. cert. & 167 & 0.929 & 0.225 & 0.000 & 1.000 \\
\hline ESCS index-ag. & 167 & 0.236 & 0.336 & -0.970 & 1.370 \\
\hline \multicolumn{6}{|l|}{ School climate: } \\
\hline Disc. clim. sci. cl. & 167 & -0.078 & 0.382 & -1.114 & 1.884 \\
\hline Tch. sup. sci. cl. & 167 & 0.190 & 0.285 & -1.702 & 0.821 \\
\hline
\end{tabular}

${ }^{1}$ Variable explanation (details in Methods): gender, males as 1; age, in years; first-gen. immig., first-generation immigrant students as 1; native students, as 1; other home lang., other language spoken at home as 1; Finn. home lang., Finnish spoken at home as 1; ESCS index, index of economic, social, and cultural status; epistemology, epistemological beliefs; enjoyment, enjoyment of science; interest, interest in broad science topics; self-efficacy, science self-efficacy; school location, community of 100,000 or larger as 1; school size, school enrollment; sci. teach. cert., index of science teachers fully certified; ESCS index-agg., index of economic, social, and cultural status, aggregated student variable; disc. clim. sci. cl., disciplinary climate in science classes, aggregated student variable and tch. supp. sci. cl., teaching support in science classes, aggregated student variable. 
Table A4. Bivariate correlations among science dispositions for Finland.

\begin{tabular}{lcccc}
\hline Key Variable & Epist. $^{\mathbf{1}}$ & Enjoyment & Interest & Self-Eff. \\
\hline Epistemology & 1.000 & $0.302^{* *}$ & $0.295^{* *}$ & $0.229^{* *}$ \\
Enjoyment & & 1.000 & $\mathbf{0 . 5 3 9} * *, 2$ & $0.363^{* *}$ \\
Interest & & 1.000 & $0.355^{* *}$ \\
Self-efficacy & & & 1.000 \\
\hline
\end{tabular}

${ }^{1}$ Variable explanation (details in Methods): epistemology, epistemological beliefs; enjoyment, enjoyment of science; interest, interest in broad science topics; self-efficacy, science self-efficacy. ${ }^{2}$ Bolded values indicate a moderate bivariate correlation among indicated pairs of variables (0.400 to 0.799$).{ }^{* *}$, Correlation is significant at the 0.01 level (2-tailed).

Table A5. Bivariate correlations among school-level variables for Finland.

\begin{tabular}{|c|c|c|c|c|c|}
\hline & School & Sci. Teach. & ESCS & Disc. Clim. & Tch. Sup. \\
\hline Key Variable & $\operatorname{size}^{1}$ & cert. & ind.-ag. & sci. cl. & sci. cl. \\
\hline School size & 1.000 & $0.200^{* *}$ & $0.232 * *$ & -0.076 & $0.160 *$ \\
\hline $\begin{array}{l}\text { Sci. teach. } \\
\text { cert. }\end{array}$ & & 1.000 & $0.268^{* *}$ & $-0.337^{* *}$ & -0.150 \\
\hline $\begin{array}{l}\text { ESCS } \\
\text { ind.-ag. }\end{array}$ & & & 1.000 & 0.051 & -0.020 \\
\hline $\begin{array}{l}\text { Disc. clim. } \\
\text { sci. cl. }\end{array}$ & & & & 1.000 & $0.267^{* *}$ \\
\hline $\begin{array}{l}\text { Tch. sup. sci. } \\
\text { cl. }\end{array}$ & & & & & 1.000 \\
\hline
\end{tabular}

$\overline{{ }^{1} \text { Variable explanation (details in the Methods section): school size, school enrollment; sci. teach. cert., index of }}$ science teachers fully certified; ESCS index-ag., index of economic, social, and cultural status, aggregated student variable; disc. clim. sci. cl., disciplinary climate in science classes, aggregated student variable; and tch. sup. sci. cl., teaching support in science classes, aggregated student variable. ${ }^{* *}, *$, correlation is significant at the 0.01 and 0.05 levels, respectively (2-tailed).

\section{References}

1. Sahlberg, P. Finnish Lessons 3.0: What Can the World Learn from Educational Change in Finland, 3rd ed.; Teachers College Press: New York, NY, USA; London, UK, 2021; p. 291.

2. OECD. PISA 2006. Science Competencies for Tomorrow's World. Available online: https://www.oecd.org/pisa/pisaproducts/ 39703566.pdf (accessed on 12 October 2021).

3. OECD. PISA 2015. PISA 2015 Results in Focus. Available online: https://www.oecd.org/pisa/pisa-2015-results-in-focus.pdf (accessed on 12 October 2021).

4. OECD. PISA 2018. PISA 2018 Results-Combined Executive Summaries, Volumes I, II, \& III. Available online: https://www. oecd.org/pisa/Combined_Executive_Summaries_PISA_2018.pdf (accessed on 12 October 2021).

5. Lavonen, J. How the Finnish compulsory school science curriculum emphasizes scientific literacy. Eest. Haridusteaduste Ajak. 2021, 9, 26-46. [CrossRef]

6. He, L.; Chen, Y.; Xiong, X.; Zou, X.; Lai, K. Does Science Literacy Guarantee Resistance to Health Rumors? The Moderating Effect of Self-Efficacy of Science Literacy in the Relationship between Science Literacy and Rumor Belief. Int. J. Environ. Res. Public Health 2021, 18, 2243. [CrossRef] [PubMed]

7. Howell, E.L.; Brossard, D. (Mis)informed about what? What it means to be a science-literate citizen in a digital world. Proc. Natl. Acad. Sci. USA 2021, 118, e1912436117. [CrossRef] [PubMed]

8. Autieri, S.M.; Amirshokoohi, A.; Kazempour, M. The science-technology-society framework for achieving scientific literacy: An overview of the existing literature. Eur. J. Sci. Math. Educ. 2016, 4, 75-89. [CrossRef]

9. Sharon, A.J.; Baram-Tsabari, A. Can science literacy help individuals identify misinformation in everyday life? Sci. Educ. 2020, 104, 873-894. [CrossRef]

10. Taylor, R.M. Open-Mindedness: An Intellectual Virtue in the Pursuit of Knowledge and Understanding. Educ. Theory 2016, 66, 599-618. [CrossRef]

11. Eklund, G. Master's thesis as part of research-based teacher education: A Finnish case. J. Teach. Educ. Educ. 2018, 8, 5-20.

12. Tirri, K. The last 40 years in Finnish teacher education. J. Educ. Teach. 2014, 40, 600-609. [CrossRef]

13. Darling-Hammond, L. Teacher education around the world: What can we learn from international practice? Eur. J. Teach. Educ. 2017, 40, 291-309. [CrossRef]

14. Niemi, H.; Toom, A.; Kallioniemi, A. Miracle of Education: The Principles and Practices of Teaching and Learning in Finnish Schools; Sense Publishers: Rotterdam, The Netherlands, 2012.

15. Beese, J.; Liang, X. Do resources matter? PISA science achievement comparisons between students in the United States, Canada and Finland. Improv. Sch. 2010, 13, 266-279. [CrossRef] 
16. OECD. PISA 2015. PISA 2015 Results (Volume I): Excellence and Equity in Education. Available online: https:/ /www.proquest. com/openview / e8c066902afa5f1a32b207d74370b87f/1?pq-origsite=gscholar\&cbl=2026456 (accessed on 13 October 2021).

17. Grabau, L.J.; Von Damme, J.; Dockx, J.; All of KU-Leuven, Leuven, Belgium. Personal Communication, 2021.

18. Murphy, S. The Impact of School Disadvantage on Senior Secondary Science: A Study of Patterns of Participation and Achievement in Government Secondary Schools in Victoria, Australia. Res. Sci. Educ. 2018, 50, 1603-1618. [CrossRef]

19. Megoğullari, M.; Guill, K.; Köller, O. Effectiveness of private tutoring during secondary schooling in Germany: Do the duration of private tutoring and tutor qualification affect school achievement? Learn. Instr. 2020, 66, 23. [CrossRef]

20. Özbay, H.E.; Köksal, M.S. Middle School Students' Scientific Epistemological Beliefs, Achievements in Science and Intellectual Risk-Taking. Sci. Educ. 2021, 30, 1233-1252. [CrossRef]

21. Forbes, C.T.; Neumann, K.; Schiepe-Tiska, A. Patterns of inquiry-based science instruction and student science achievement in PISA 2015. Int. J. Sci. Educ. 2020, 42, 783-806. [CrossRef]

22. Zhang, F.; Bae, C.L.; Broda, M. Science Self-Concept, Relatedness, and Teaching Quality: A Multilevel Approach to Examining Factors that Predict Science Achievement. Int. J. Sci. Math. Educ. 2021, 1-27. [CrossRef]

23. OECD. PISA 2006. PISA 2006 Technical Report. Available online: http://www.oecd.org/pisa/pisaproducts/42025182.pdf (accessed on 12 October 2021).

24. Karakoldis, A.; Educational Research Centre, St Patrick's Campus, Drumcondra, Dublin. Personal Communication, 2020.

25. Grabau, L.J.; Ma, X. Science engagement and science achievement in the context of science instruction: A multilevel analysis of U.S. students and schools. Int. J. Sci. Educ. 2017, 39, 1045-1068. [CrossRef]

26. Grabau, L.J. International secondary science education: Associations among science epistemology, science enjoyment, school climate and science achievement. In Proceedings of the American Educational Research Association Annual Meeting, Virtual, 8-12 April 2021.

27. Lau, K.-C.; Ho, S.-C.E. Attitudes Towards Science, Teaching Practices, and Science Performance in PISA 2015: Multilevel Analysis of the Chinese and Western Top Performers. Res. Sci. Educ. 2020, 12. [CrossRef]

28. Radišić, J.; Selleri, P.; Carugati, F.; Baucal, A. Are students in Italy really disinterested in science? A person-centered approach using the PISA 2015 data. Sci. Educ. 2021, 105, 438-468. [CrossRef]

29. Teppo, M.; Soobard, R.; Rannikmae, M. Grade 6 \& 9 student and teacher perceptions of teaching and learning approaches in relation to student pereceived interest/enjoyment towards science learning. J. Baltic Sci. Educ. 2021, 20, 119-133. [CrossRef]

30. McConney, A.; Woods-McConney, A. Inquiry-based, teacher-directed and adaptive instruction in secondary science: A crossnational analysis of associations with science literacy and interest using PISA2015. In Proceedings of the ICERI2019 Conference, Seville, Spain, 11-13 November 2019.

31. Inkinen, J.; Klager, C.; Juuti, K.; Schneider, B.; Salmela-Aro, K.; Krajcik, J.; Lavonen, J. High school students' situational engagement associated with scientific practices in designed science learning situations. Sci. Educ. 2020, 104, 667-692. [CrossRef]

32. Juuti, K.; Lavonen, J.; Salonen, V.; Salmela-Aro, K.; Schneider, B.; Krajcik, J. A Teacher-Researcher Partnership for Professional Learning: Co-Designing Project-Based Learning Units to Increase Student Engagement in Science Classes. J. Sci. Teach. Educ. 2021, 32, 625-641. [CrossRef]

33. Salmela-Aro, K.; Upadyaya, K.; Cumsille, P.; Lavonen, J.; Avalos, B.; Eccles, J. Momentary task-values and expectations predict engagement in science among Finnish and Chilean secondary school students. Int. J. Psychol. 2020, 56, 415-424. [CrossRef]

34. Upadyaya, K.; Cumsille, P.; Avalos, B.; Araneda, S.; Lavonen, J.; Salmela-Aro, K. Patterns of situational engagement and task values in science lessons. J. Educ. Res. 2021, 114, 394-403. [CrossRef]

35. Lee, S.W.; Luan, H.; Lee, M.; Chang, H.; Liang, J.; Lee, Y.; Lin, T.; Wu, A.; Chiu, Y.; Tsai, C. Measuring epistemologies in science learning and teaching: A systematic review of the literature. Sci. Educ. 2021, 105, 880-907. [CrossRef]

36. Schiefer, J.; Bernholt, A.; Kampa, N. A closer look at elementary students' epistemic beliefs-latent profiles capturing concepts of knowledge and knowing in science. Learn. Ind. Diff. 2021, 92, 16. [CrossRef]

37. She, H.; Lin, H.; Huang, L. Reflections on and implications of the Programme for International Student Assessment 2015 (PISA 2015) performance of students in Taiwan: The role of epistemic beliefs about science in scientific literacy. J. Res. Sci. Teach. 2019, 56, 1309-1340. [CrossRef]

38. OECD. PISA 2015. PISA 2015 Technical Report. Available online: http://www.oecd.org/pisa/data/2015-technical-report/ (accessed on 12 October 2021).

39. Juuti, K.; Loukomies, A.; Lavonen, J. Interest in Dialogic and Non-Dialogic Teacher Talk Situations in Middle School Science Classroom. Int. J. Sci. Math. Educ. 2019, 18, 1531-1546. [CrossRef]

40. Alatl, B.K. Investigation of Factors Associated with Science Literacy Performance of Students by Hierarchical Linear Modeling: PISA 2015 Comparison of Turkey and Singapore. Egiptim Ve Bilim Educ. Sci. 2020, 45, 17-49. [CrossRef]

41. OECD. PISA 2015. Student Questionnaire, PISA 2015. Available online: https://www.oecd.org/pisa/data/CY6_QST_MS_STQ_ CBA_Final.pdf (accessed on 12 October 2021).

42. Ma, X.; Wu, X.; Yuan, J.; Luo, X. Students, classrooms, teachers, and schools: Competing effects on science achievement. Teach Coll. Rec. 2018, 120, 48. [CrossRef]

43. OECD. PISA 2015. PISA 2015 Database. Available online: https://www.oecd.org/pisa/data/2015database/ (accessed on 13 October 2021). 
44. IBM. SPSS-26 Release Specifications. Available online: https://www.ibm.com/support/pages/release-notes-ibm\%C2\%AEspss $\%$ C2\%AE-statistics-260 (accessed on 13 October 2021).

45. Valladares, L. Scientific Literacy and Social Transformation. Sci. Educ. 2021, 30, 557-587. [CrossRef]

46. Aditomo, A.; Köhler, C. Do student ratings provide reliable and valid information about teaching quality at the school level? Evaluating measures of science teaching in PISA 2015. Educ. Assess. Eval. Acc. 2020, 32, 275-310. [CrossRef]

47. Ma, X.; Ma, L.; Bradley, K. Using multilevel modeling to investigate school effects. In Multilevel Modeling of Educational Data; O'Connell, A.A., McCoach, D.B., Eds.; Information Age: Charlotte, NC, USA, 2008; pp. 59-110.

48. Raudenbush, S.W.; Bryk, A.S. Hierarchical Linear Models: Applications and Data Analysis Methods, 2nd ed.; SAGE: Thousand Oaks, CA, USA, 2002; Volume 1.

49. Scientific Software International. HLM 8 for Windows. Available online: http://www.ssicentral.com/index.php/product/hlm (accessed on 13 October 2021).

50. Cohen, J. Statistical Power Analysis for the Behavioral Sciences, 2nd ed.; Lawrence Erlbaum: Hillsdale, NJ, USA, 1988.

51. Scherer, R. The case for good discipline? Evidence on the interplay between disciplinary climate, socioeconomic status, and science achievement from PISA 2015. In Equity, Equality and Diversity in the Nordic Model of Education; Frønes, T.S., Pettersen, A., Radišić, J., Buchholtz, N., Eds.; Springer: Cham, Switzerland, 2020. [CrossRef]

52. Chi, S.; Liu, X.; Wang, Z.; Han, S.W. Moderation of the effects of scientific inquiry activities on low SES students' PISA 2015 science achievement by school teacher support and disciplinary climate in science classroom across gender. Int. J. Sci. Educ. 2018, 40, 1284-1304. [CrossRef]

53. Kang, J. Interrelationship Between Inquiry-Based Learning and Instructional Quality in Predicting Science Literacy. Res. Sci. Educ. 2020, 1-17. [CrossRef]

54. Lavonen, J.; Angell, C.; Byman, R.; Henriksen, E.K.; Koponen, I.T. Social Interaction in Upper Secondary Physics Classrooms in Finland and Norway: A survey of students' expectations. Scand. J. Educ. Res. 2007, 51, 81-101. [CrossRef]

55. Lonka, K.; Ketonen, E.; Vermunt, J.D. University students' epistemic profiles, conceptions of learning, and academic performance. High. Educ. 2020, 81, 775-793. [CrossRef]

56. Park, S.; Kite, V.; Suh, J.K.; Jung, J.; Rachmatullah, A. Investigation of the relationships among science teachers' epistemic orientations, epistemic understanding, and implementation of Next Generation Science Standards science practices. J. Res. Sci. Teach. 2021. [CrossRef]

57. Hampden-Thompson, G.; Bennett, J. Science Teaching and Learning Activities and Students' Engagement in Science. Int. J. Sci. Educ. 2013, 35, 1325-1343. [CrossRef]

58. Kumpulinen, K. Teachers and Principals in Finland 2016. Available online: https://www.oph.fi/sites/default/files/documents/ opettajat_ja_rehtorit_suomessa_2016_0.pdf (accessed on 15 October 2021).

59. Rupérez, F.L.; García, I.G.; Expósito-Casas, E. Educational Effectiveness, Efficiency, and Equity in Spanish Regions: What does PISA 2015 Reveal? Orb. Sch. 2019, 12, 9-36. [CrossRef]

60. Van Laere, E.; Aesaert, K.; Van Braak, J. The Role of Students' Home Language in Science Achievement: A multilevel approach. Int. J. Sci. Educ. 2014, 36, 2772-2794. [CrossRef]

61. Grabau, L.J. Science Education: Lessons from Abroad, Drawn from PISA-2015; American Society of Agronomy: Salt Lake City, UT, USA, 2021.

62. Agirdag, O.; VanLaar, G. Does more exposure to the language of instruction lead to higher academic achievement? A crossnational examination. Int. J. Biling. 2016, 22, 123-137. [CrossRef]

63. Goodrich, J.M.; Thayer, L.; Leiva, S. Evaluating Achievement Gaps Between Monolingual and Multilingual Students. Educ. Res. 2021, 50, 429-441. [CrossRef]

64. Smith, P.; Frazier, P.; Lee, J.; Chang, R. Incongruence Between Native and Test Administration Languages: Towards Equal Opportunity in International Literacy Assessment. Int. J. Test. 2017, 18, 276-296. [CrossRef]

65. Fung, D. Teaching Science Through Home and Second Languages as the Medium of Instruction: A Comparative Analysis of Junior Secondary Science Classrooms in Hong Kong. Int. J. Sci. Math. Educ. 2020, 19, 1609-1634. [CrossRef] 